ENCYCLOPEDDIE Encyclopédie berbère

BERBERE

1 | 1984

1 | Abadir - Acridophagie

\title{
'Abd al Salām
}

G. Camps

\section{OpenEdition}

Journals

Édition électronique

URL : http://journals.openedition.org/encyclopedieberbere/779

DOI : 10.4000/encyclopedieberbere. 779

ISSN : 2262-7197

\section{Éditeur}

Peeters Publishers

\section{Édition imprimée}

Date de publication : 1 novembre 1984

Pagination : 70

ISBN : 2-85744-201-7

ISSN : 1015-7344

\section{Référence électronique}

G. Camps, «'Abd al Salām », Encyclopédie berbère [En ligne], 1 | 1984, document A11, mis en ligne le 01 décembre 2012, consulté le 05 octobre 2020. URL : http://journals.openedition.org/ encyclopedieberbere/779; DOI : https://doi.org/10.4000/encyclopedieberbere.779

Ce document a été généré automatiquement le 5 octobre 2020.

(c) Tous droits réservés 


\section{'Abd al Salām}

\section{G. Camps}

1 Saint marocain, adepte du soufisme, qui périt assassiné en $625 / 1227$. Sa vie est en grande partie légendaire. Il exerça son autorité spirituelle sur les Banu 'Arūs et souffrit de la rivalité de Muhammad ben 'Ali Tuājin chef religieux des Kotāma (à ne pas confondre avec les Ketama* d'Ifriqiya) qui le fit mettre à mort.

2 Sidi 'Abd al Salam fut enterré sur le jbel 'Alam. Son tombeau devint l'objet de pèlerinages importants et le siège de nombreux miracles.

\section{BIBLIOGRAPHIE}

RINN L. Marabouts et Khouan. Alger, 1884, p. 218-219.

MOULIERAS A. Le Maroc inconnu, t. 2 ; Paris, 1899, p. 157-178.

BASSET R. Nédromah et les Traras, Paris, Leroux, 1901, p. 69.

MONTET E. Le culte des saints musulmans dans l'Afrique du Nord et plus spécialement au Maroc, Genève, 1909.

DERMENGHEM E. Le culte des saints dans l'Islam maghrébin, Coll. L'Espèce humaine, 1954, Paris, Gallimard, 1954.

\section{INDEX}

Mots-clés : Biographie, Maroc 